Perlea Paula ${ }^{1}$, Gheorghiu Irina-Maria ${ }^{2}$, Ciolan C.G. ${ }^{3}$, Mitran Loredana ${ }^{4}$, Scarlatescu Sanziana ${ }^{1}$, Margarit Ruxandra ${ }^{2}$, Mitran M. ${ }^{5}$

\title{
Direct odontal restoration with pre-fabricated screw metal post- case report
}

${ }^{1}$ Department of Endodontics, Faculty of Dental Medicine, UMF "Carol Davila" Bucharest

${ }^{2}$ Department of Restorative Odontotherapy, Faculty of Dental Medicine, UMF "Carol Davila" Bucharest

${ }^{3}$ Private dental Practice, True Stomartists, Bucharest

${ }^{4}$ Department of Otorhinolaryngology, Elias Hospital

${ }^{5}$ Department of Obstetrics and Gynecology, Faculty of Medicine, UMF "Carol Davila" Bucharest

\begin{abstract}
We are very often confronted in dental daily practice with the clinical situations where important loss of hard dental structure is present and direct restoration is required. In these cases, armed odontal direct restauration can be performed, using additional retention systems. The restoration of the coronal part in nonvital teeth has certain specific aspects and one of the most used endodontic anchorage is the metal threaded prefabricated posts. Current techniques and materials allow the dentist to fulfill all the clinical requirements, in terms of resistance to occlusal stress and the esthetic aspect of the restoration.
\end{abstract}

Key words: direct odontal restoration; non-vital tooth; screw metal post

Irina-Maria Gheorghiu

Faculty of Dental Medicine, UMF "Carol Davila" Bucharest Calea Plevnei 17-23, Bucharest

email : igheorghiu@hotmail.com phone: +40744305591

\section{Introduction}

Odontal direct restorations currently occupy an increasingly important place in modern dental medicine. In the case of teeth with extensive loss of dental tissue, direct restorations are made using additional retention systems [1]. These can be used on both vital teeth (dental pins), but more often they are used on endodontically treated teeth (prefabricated metal posts, or posts made from quartz, ceramic, zirconia, carbon or glass fiber) $[2,3,4]$. The use of prefabricated posts is associated with the direct coronal reconstruction of the tooth using different dental materials as: amalgam, resin composite or glass ionomer cements. In the case of non-vital teeth, cast or prefabricated endodontic posts are used to ensure additional retention [5]. The prefabricated metal pins are made of: stainless steel, titanium, platinum-goldpalladium, alloy containing chromium, copper and zinc alloy and covered with a uniform protective layer of gold $24 \mathrm{~K}$ ( gold plated posts). 


\section{Case report}

A male patient, 25 years old, presented to our dental practice for dental treatment. We indentified the presence of an extensive coronal lesion in tooth no. 15 . The clinical examination revealed the existence of a profound carious lesion (Figure 1.), which produced the massive coronary destruction of the tooth.

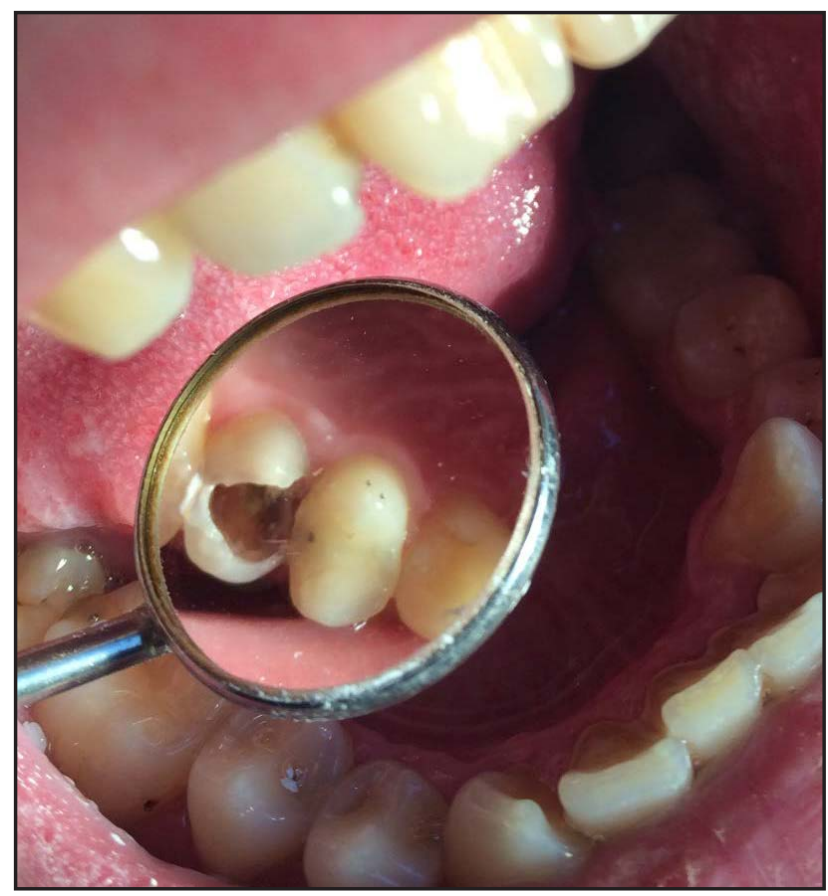

Figure 1 - Clinical view of extended carious lesion in tooth 15.

The radiological examination confirmed the existence of a correct endodontic treatment. The important coronal hard tissues loss has led us to choose a direct odontal armed restoration using resin composite material and a pre-fabricated screw metal post. We used a threaded metal post made of copper and zinc alloy and covered with a $24 \mathrm{~K}$ : Gold Plated Screw Posts ${ }^{\circledR}$ (Swe Dent).

The gold-plated metal posts are not expensive, have good mechanical resistance, are radiopaque and are biocompatible with dental tissues. Threaded posts are more retentive than cemented ones, but create more dentin stress during insertion [6,7]. To reduce the internal stress created by the threaded pins, limit the number of threads and release one thread by a reverse movement at the end of post insertion, have been taken into consideration $[8,9]$.

The technique used in the restorative treatment of this case is the technique of direct placement of composite materials using a light-curing universal microhybrid composite: Filtek Z 250® (3M ESPE). The adhesive used was $3 \mathrm{M}$ Single Bond Dental Adhesive ${ }^{\circledR}$ (3M ESPE).

The dental session began with checking the remaining dental tissues and removing the areas with altered dentin or decalcified enamel. The isolation was applied and then the preparation of the root canals with Peeso Reamers ${ }^{\circledR}$ (Mani) drills of different sizes was made in order to insert the metal pivot (Figure 2).

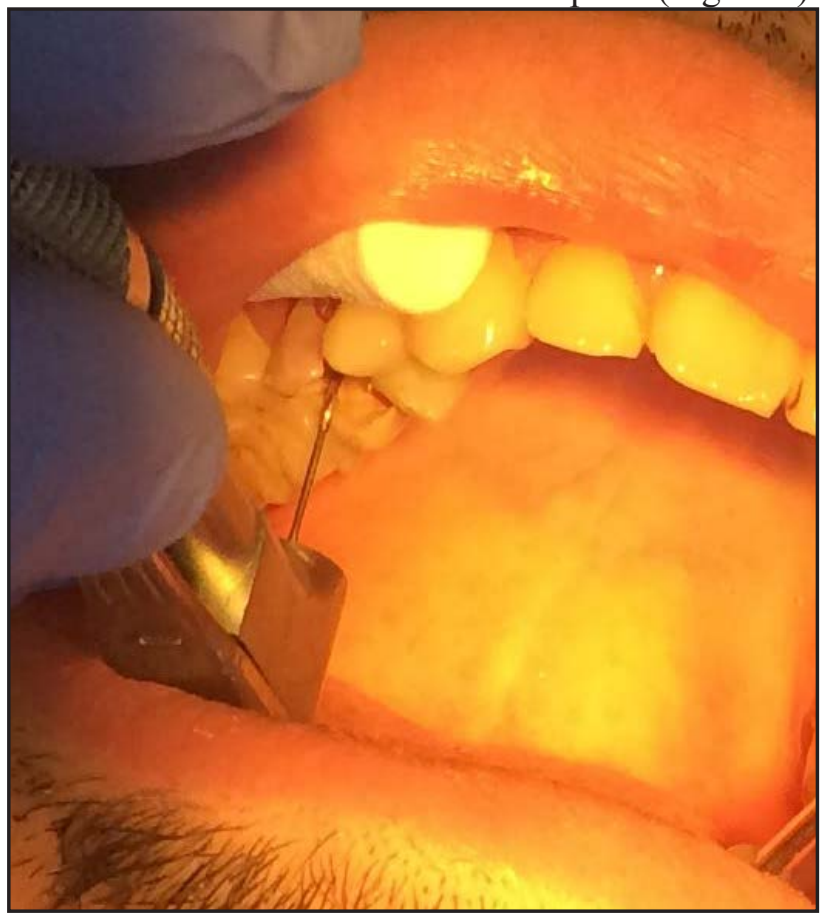

Figure 2 - The preparation of the root canal with Peeso Reamers ${ }^{\circledR}$ (Mani)

After cleaning and removing all the resulted debris inside root canal and coronal cavity, the pivot was selected and inserted into the prepared endodontic space (Figures 3, 4, 5). 


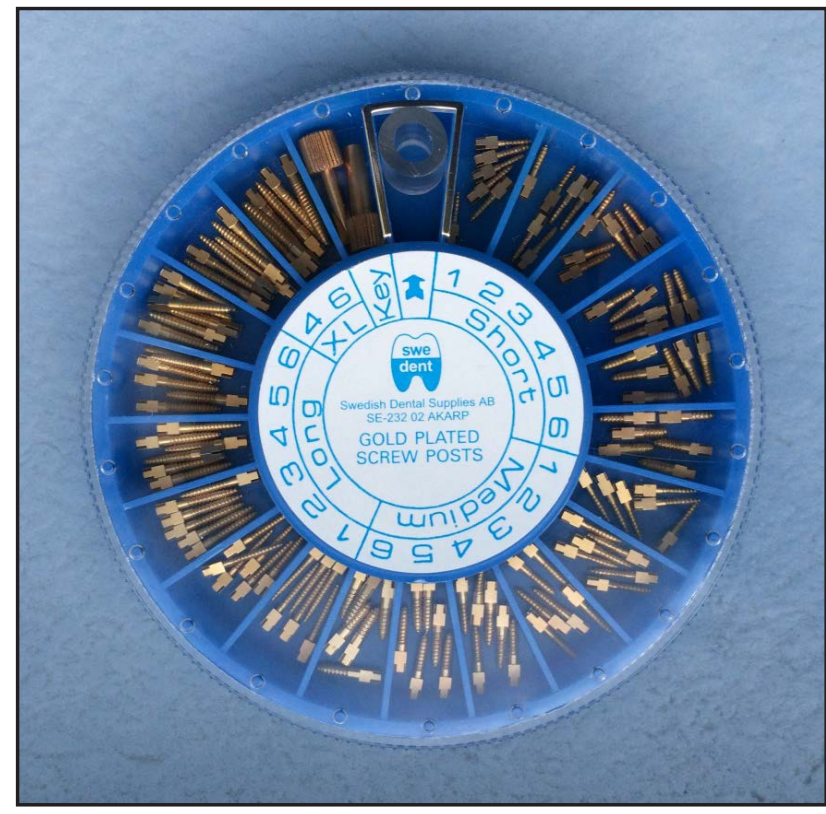

Figure 3 - Gold Plated Screw Posts ${ }^{\circledR}$ Swe Dent)

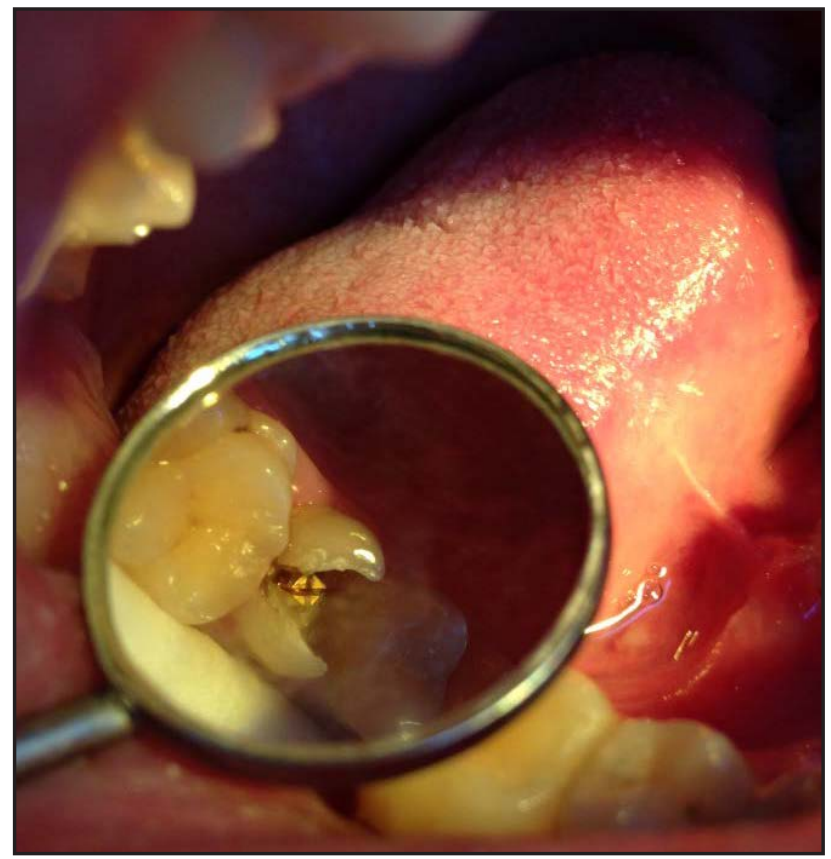

Figure 4 - The insertion of the screw post into the prepared root canal

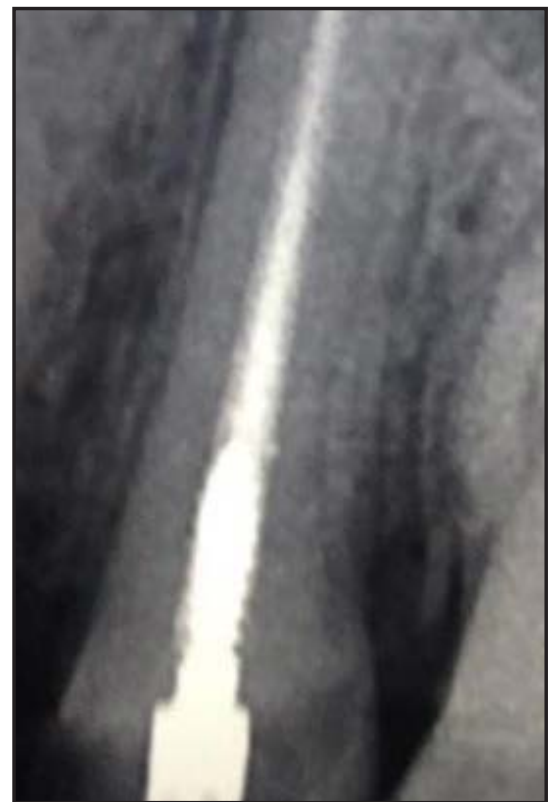

Figure 5 - The radiological image of the inserted intraradicular screw post

In order to realize the direct odontal resin composite restoration, the cavity was acid-etched with $3 \mathrm{M}$ Universal Etchant, Scochbond ${ }^{\circledR}$ (3M ESPE) $35 \%$ phosphoric acid for 20 seconds and rinsed thoroughly. When the acid-etching was complete, the adhesive system 3M Single Bond Dental Adhesive ${ }^{\circledR}$ (3M ESPE) was applied, then thinned, dried for 2-5 seconds and light-cured for 20 seconds.

Next, a Tofflemire (Dentalmart) circular matrix was applied to the tooth to allow correct coronal restoration. The resin composite material was then applied in successive layers inside the cavity. The insertion technique of composite into the cavity was oblique incremental technique. Every layer of resin composite has been light-cured for 20 seconds.

The occlusal adjustment of the restoration have been made using articulating paper and diamond burs (Dia-Burs ${ }^{\circledR}$, MANI) after matrix removal. Finishing and polishing of the restoration was accomplished with dental fine grit polishers (Kenda). The final result of endodontic armed coronal restoration in tooth 15 is presented in Figure 6. 


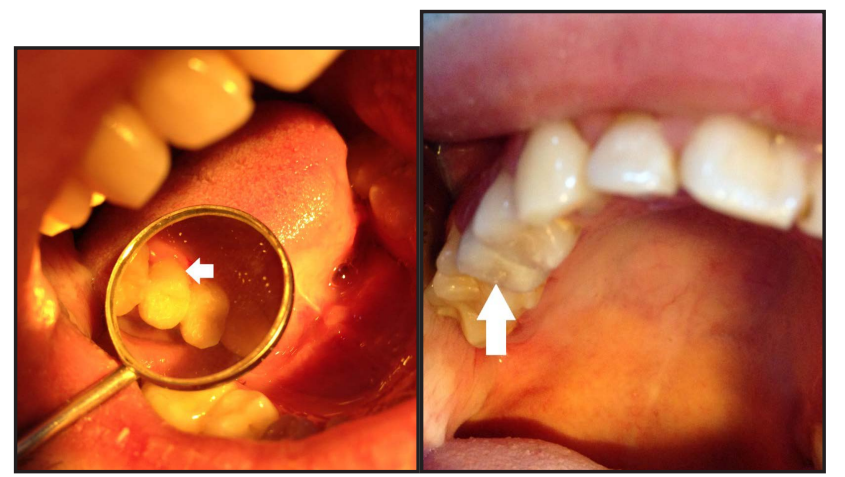

Figure 6 - The final result of endodontic armed coronal restoration in tooth 15 .

\section{Conclusions}

In clinical situations where direct odontal restorations are performed, and loss of dental hard substance is important, additional retention systems is the first choice for retention and stability of the coronal restorative material $[10,11,12]$. By contrast with the direct restorations in vital teeth, the restoration of the coronal part in non-vital teeth has certain specific aspects. Massive tissue destruction, as well as the sacrifice of hard dental substance resulting from the access of the endodontic instruments, cause difficulties in ensuring retention of the restorative material. Current techniques allow the dentist to meet all the clinical requirements, in terms of resistance to occlusal stress and the esthetic aspect of the restoration.

\section{Acknowledgements}

For this article all the authors have equal contributions.
References

1. Iliescu, A. \& Gafar, M. (2011). Cariologie si odontoterapie restauratoare. Ed. Medicala, Bucuresti.

2. Vârlan, C. \& Dimitriu, B. (2009). Concepte terapeutice şi modalităţi clinice de restaurare coronară a dinţilor trataţi endodontic. Editura Universitară "Carol Davila", Bucureşti.

3. Fokkinga, W.A., Fennis, W.M., Witter, D.J., Kreulen, C.M. \& Creugers, N.H. (2013). [Buildup restorations after extensive loss of tooth tissue]. Ned Tijdschr Tandheelkd. 120(2), 81-90..

4. Mount, G.J. \& Hume, W.R. (1999). Conservarea şi restaurarea structurii dentare, Ed. ALL Educational.

5. Schwartz, R.S. \& Robbins, J.W. (2004). Post placement and restoration of endodontically treated teeth: a literature review. J Endod. 30(5), 289-301. doi: 10.1097/00004770-20040500000001.

6. Al-Omiri, M.K., Mahmoud, A.A., Rayyan, M.R. \& Abu-Hammad, O. (2010). Fracture resistance of teeth restored with post-retained restorations: an overview. J Endod. 36(9), 1439-1449. doi: 10.1016/j.joen.2010.06.005.

7. Akkayan, B. \& Gulmez, T. (2002). Resistance to fracture of endodontically treated teeth restored with different post systems. J Prosthet Dent. 87(4), 431-437.

8. Assif, D. \& Gorfil, C. (1994). Biomechanical considerations in restoring endodontically treated teeth. J Prosthet Dent. 71(6), 565-567.

9. Peroz, I., Blankenstein, F., Lange, K.P. \& Naumann, M. (2005). Restoring endodontically treated teeth with posts and cores--a review. Quintessence Int. 36(9), 737-746.

10. Gheorghiu, I. (2013). Complicațiile distructiilor dentare coronare. Ed. Universitară Carol Davila. București.

11. Kakaboura, A., Shearer, A.C., Vanherle, G. \& Wilson, N.H. (2014). Guidance on posterior resin composites. Academy of Operative Dentistry - European Section. J Dent. 42(4), 
377-83.

12. Bohaty, B.S., Ye, Q., Misra, A., Sene, F. \& Spencer, P. (2013). Posterior composite restoration update: focus on factors influencing form and function. Clin Cosmet Investig Dent. 5, 33-42. doi: 10.2147/ccide. s42044. 